\title{
Terapi psikoreligi terhadap penurunan perilaku kekerasan pada pasien Skizofrenia di ruang rawat inap Rumah Sakit Jiwa Daerah Provinsi Lampung
}

\author{
Teguh Pribadi ${ }^{*}$, Djunizar Djamaludin² \\ 1,2Program Studi Ilmu Keperawatan, Fakultas Kedokteran Universitas Malahayati Bandar Lampung \\ *Email : teguh@malahayati.ac.id
}

\begin{abstract}
Psycho-religious therapy in reducing violent behavior among patients with Schizophrenia
\end{abstract}

Background: The main problem that often occurs to patients with schizophrenia is violent behavior. Violent behavior is a state in which a person performs a physically harmfulserve to himself or to another person. Psychoreligious therapy is a therapy that is usually through a religiousreligion approach such as client believed according their riligion and tends to touch the spiritual side of man and also rather to awaken the spiritual power against of with illness. Data reported to Lampung Mental Hospital, the trend number of violent behavior was increasing and data in 2018 as many as 194 patients with violent behavior.

Purpose: Knowing effectiveness of psycho-religious therapy in reducing violent behavior among patients with schizophrenia Lampung Mental Hospital 2019

Methods: A quantitative and quasi experiment with two group pretest postest design. the population of this study were all patients with violent behavior in the inpatient ward of Lampung mental hospital as many as 30 patients. this research instrument used observation sheet. statistical analysis used t dependent tests.

Result: Finding the mean score of violent behavior behavior before psychoreligious therapy were of 16.87 with a standard deviation of 1.46, and after psycho religious therapy was 13.0 with a standard deviation of 1.0.

Conclusion: There was an influence of psycho religious therapy in reducing violent behavior inpatients with schizophrenia ( $p$ value 0,000 ).

Suggestion: The hospital management to apply psychoreligious therapy programs to patients with schizophrenia specially patients has risk of violent behavior

\section{Keywords: Psychoreligious Therapy; Violence Behavior; Schizophrenia}

Pendahuluan: Permasalahan utama yang sering terjadi pada pasien Skizofrenia adalah perilaku kekerasan. Perilaku kekerasan adalah suatu keadaan dimana seseorang melakukan tindakan yang membahayakan secara fisik, baik kepada diri sendiri, maupun orang lain. Terapi psikoreligius adalah terapi yang biasanya melalui pendekatan keagamaan yang dianut oleh klien dan cenderung untuk menyentuh sisi spiritual manusia, untuk membangkitkan kekuatan spiritual dalam menghadapi penyakit yang dideritanya Dari data yang diperoleh dari Rumah Sakit Jiwa Daerah Provinsi Lampung jumlah pasien dengan prilaku kekerasan cenderung meningkat dan data di tahun 2018 sebanyak 194 pasien dengan perilaku kekerasan.

Tujuan: Mengetahui pengaruh terapi psikoreligi terhadap penurunan perilaku kekerasan pada pasien skizopfrenia di ruang rawat inap Rumah Sakit Jiwa Daerah Provinsi Lampung Tahun 2019.

Metode: Penelitian kuantitatif menggunakan Quasi Eksperiment dengan two group pretest postest. Populasi dan sampelnya seluruh pasien dengan perilaku kekerasan di Ruang Rawat Inap Rumah Sakit Jiwa Daerah Provinsi Lampung sebanyak 30 pasien. Instrumen penelitian ini menggunakan lembar observasi. Analisastatistik yang digunakan yaitu uji $t$ Dependen.

Hasil: Didapatkan nilai rata-rata skor perilaku kekerasan Sebelum Terapi psikoreligi adalah 16,87 dengan standar deviasi 1,46, rata-rata Skor perilaku kekerasan sesudah Terapi psikoreligi adalah 13.0 dengan standar deviasi 1,0 .

Simpulan: Ada pengaruh terapi psikoreligi terhadap penurunan perilaku kekerasan pada pasien skizopfrenia di Ruang Rawat Inap Rumah Sakit Jiwa Daerah Provinsi Lampung Tahun 2019 ( $p$ value 0,000).

Saran: Ditujukan kepada pihak manajemen rumah sakit agar menerapakan program terapi psikoreligius pada pasien schizophrenia dengan perilaku kekerasan.

Kata Kunci: Terapi Psikoreligi; Perilaku Kekerasan; Skizopfrenia 
Terapi psikoreligi terhadap penurunan perilaku kekerasan pada pasien Skizofrenia di ruang rawat inap Rumah Sakit Jiwa Daerah Provinsi Lampung

\section{PENDAHULUAN}

Prevalensi gangguan jiwa menurut $\mathrm{WHO}$ tahun 2013 mencapai 450 juta jiwa diseluruh dunia, dalam satu tahun sesuai jenis kelamin sebanyak 1,1 wanita, pada pria 0,9 sementara jumlah yang mengalami gangguan jiwa seumur hidup sebanyak 1,7 jiwa wanita dan 1,2 pria. Menurut National of Mental Health (NIMH) berdasarkan hasil sensus penduduk Amerika Serikat diperkirakan 26,2\% penduduk yang berusia 18 tahun atau lebih mengalami gangguan jiwa NIMH. Prevalensi gangguan jiwa cukup tinggi dan terjadi pada usia produktif (Gusdiansyah, 2016). Setiap tahun, jumlah penderita gangguan jiwa terus meningkat, baik gangguan jiwa berat maupun ringan. Namun sayangnya, masih sedikit yang memiliki perhatian terhadap kesehatan jiwa. Program promosi kesehatan jiwa di masyarakat pun masih belum banyak (Suryani, 2013). Berdasarkan hasil Riset Kesehatan Dasar (Riskesdas) 2013 gangguan jiwa berat (psikosis atau skizofrenia) di Provinsi Lampung sebesar 0,8 per 1000 penduduk (Kementrian Kesehatan Republik Indonesia, 2013). Data Rumah Sakit Jiwa Provinsi Lampung tahun 2015 jumlah penderita gangguan jiwa berjumlah 17.465orang dan 8.007 orang $(45,8 \%)$ mengalami skizofrenia dan penderita gangguan jiwa meningkat ditahun 2016 menjadi 17.767 orang dan 8243 orang $(46,3 \%)$ mengalami skizofrenia (Rumah Sakit Jiwa Provinsi Lampung, 2017).

Prevalensi penderita skizoprenia di Indonesia adalah $0,3-1 \%$. Apabila penduduk Indonesia sekitar 200 juta jiwa, maka diperkirakan sekitar 2 juta jiwa menderita skizoprenia. Skizoprenia adalah gangguan mental yang sangat luas dialami di Indonesia, dimana sekitar 99\% Rumah Sakit Jiwa di Indonesia adalah penderita skizoprenia (Departemen Kesehatan Republik Indonesia, 2010).

Permasalahan utama yang sering terjadi pada pasien skizoprenia adalah perilaku kekerasan. Hal ini sesuai dengan diagnosa keperawatan NANDA yang biasa ditegakkan berdasarkan pengkajian gejala psikotik atau tanda positif. Kondisi ini harus segera ditangani karena perilaku kekerasan yang terjadi akan membahayakan diri pasien, orang lain, dan lingkungan. Hal ini yang menjadi alasan utama pasien skizoprenia dibawa ke rumah sakit.

Perilaku kekerasan adalah suatu keadaan dimana seseorang melakukan tindakan yang dapat membahayakan secara fisik baik terhadap diri sendiri, orang lain, maupun lingkungan. Hal tersebut dilakukan untuk mengungkapkan perasaan kesal atau marah yang tidak konstruktif (Stuart \& Sundeen, 2006; Sulistyowati, \& Prihantini, 2015). Perilaku kekerasan merupakan respon stressor yang dihadapi oleh seseorang, yang ditunjukan dengan perilaku aktual melakukan kekerasan baik pada diri sendiri maupun lingkungan, secara verbal maupun nonverbal, bertujuan untuk melukai orang secara fisik maupun psikologis (Yosep, 2009). Perilaku kekerasan di tandai dengan adanya muka marah, tegang dan emosi. Pasien mengalami distorsi kognitif seperti merasa diri paling berkuasa, pengasingan, mengkritik pendapat orang lain dan putus asa. Terdapat rasa malas dan menarik diri hubungan sosial. Pasien mengalami gangguan tidur seperti sulit masuk tidur atau terbangun dini hari. Nafsu makan berkurang begitu juga dengan sexsual (Yosep, 2007; Damaiyanti, 2008).

Dari data yang diperoleh dari RSJD jumlah pasien prilaku kekerasan cenderung meningkat. Pada tahun 2014 pasien dengan perilaku kekerasan yang dirawat sebanyak 178 orang, sedangkan pada tahun 2015 mengalami peningkatan sebanyak 194 orang. Dari data yang di peroleh saat presurve didapatikan bahwa pasien yang paling banyak di rawat di rawat inap adalah pasien dengan riwayat resiko perilaku kekerasan, dengan total 46 pasien yang mempunyai riwayat resiko prerilaku kekerasan dalam 11 bulan terakhir terakhir dari total pasien keseluruhan 186 jiwa. Maramis mengidentifikasi penyebab gangguan dapat berasal dari masalah fisik, kondisi kejiwaan (psikologis), dan masalah sosial (lingkungan). Apabila gangguan jiwa disebabkan karena masalah fisik, yaitu terjadinya gangguan keseimbangan neurotransmiter yang mengendalikan perilaku manusia, maka pilihan pengobatan pada farmakologi. Apabila penyebab gangguan jiwa karena masalah psikologis, maka dapat diselesaikan secara psikologis dan bila penyebab gangguan karena masalah lingkungan sosial, maka pilihan terapi difokuskan pada manipulasi lingkungan. Dengan demikian, berbagai macam terapi dalam keperawatan kesehatan jiwa dapat berupa somatoterapi, psikoterapi, dan terapi lingkungan (Maramis, 2009).

Terapi yang dilakukan pada pasien skizofrenia meliputi: terapi psikofarmaka, psikoterapi, terapi psikososial, dan terapi psikoreligius.Terapi

Teguh Pribadi $i^{*}$, Djunizar Djamaludin ${ }^{2}$ Program Studi llmu Keperawatan, Fakultas Kedokteran

Universitas Malahayati Bandar Lampung. ${ }^{* E m a i l: ~ t e g u h @ m a l a h a y a t i . a c . i d ~}$ 
Terapi psikoreligi terhadap penurunan perilaku kekerasan pada pasien Skizofrenia di ruang rawat inap Rumah Sakit Jiwa Daerah Provinsi Lampung

psikoreligius adalah terapi yang biasanya melalui pendekatan keagamaan yang dianut oleh klien dan cenderung untuk menyentuh sisi spiritual manusia. Salah satu bentuk terapi psikoreligius antara lain zikir. Terapi yang menggunakan media zikir mengingat Allah yang bertujuan untuk menenangkan hati dan memfokuskan pikiran. Dengan bacaan do'a dan zikir orang akan menyerahkan segala permasalahan kepada Allah, sehingga beban stress yang dihimpitnya mengalami penurunan (Hawari, 2001; Fanada, 2012). Di dalam ajaran agama Islam adanya penyakit itu dianggap sebagai suatu cobaan dan ujian keimanan seseorang, oleh karenanya orang harus bersabar dan tidak boleh berputus asa berusaha untuk mengobatinya dengan senantiasa berdoa memohon pertolongan Allah swt, maka bagi umat yang beragama derdoa dan berdzikir ( mengiat Tuhan) dikala sedang menghadapi musibah (penyakit) merupakan upayayang amat dianjurkan guna memperoleh ketenangan dan penyembuhan penyakit. Hal ini sesuai dengan hasil penelitian yang dilakukan oleh snyderman yang berkesimpulan bahwa: "Terapi medis tampa doa dan dzikir, tidak lengkap; doa dan dzikir saja tampa terapi medis, tidak efektif" (Rahmat, 2009). Terapi keagamaan (psokoreligius) terhadap penderita Skizofrenia ternyata mempunyai manfaat. Dari penelitian yang dilakukan, secara umum memang menunjukan bahwa komitmen agama berhubunganan dengan manfaatnya di bidang klinik. Larson dalam penelitiannya membandingkan keberhasilan terapi terhadap dua kelompok penderita Skizofrenia. Kelompok pertama mendapat terapi yang konvensional (psikofarma) dan lain-lainnya tetapi tidak mendapatkan terapi keagamaan. Kelompok kedua mendapatkan terapi yang konvesional (psikofarma) dan terap lain-lainnya serta mendapatkan terapi keagamaan. Kedua kelompok tersebut di rawat di Rumah Sakit Jiwa yang sama. Hasilnya dibandingkan ternyata cukup bermakna Terapi keagamaan yang dimaksudkan dalam penelitian di atas adalah berupa kegiatan ritual keagamaan seperti sembahyang, berdoa, memanjatkan pujipujian kepada tuhan, ceramah keagamaan dan kajian kitab suci dan lain sebagainya (Hawari, 2003; Kusuma, 2015). Respon emosional yang positif atau dari pengaruh terapi psikoreligius dengan doa dan dzikir ini berjalan mengalir dalam tubuh dan diterima oleh batang otak. Setelah diformat dengan bahasa otak, kemudian ditransmisikan ke salah satu bagian otak besar yakkni thalamus, kemudian, Thalamus menstansmisikan impuls hipokampus (pusat memori yang vital untuk mengkoordinasikan segala hal yang diserap indera) untuk mensekresikan GABA (Gama Amino Batiric Acid) yang bertugas sebagai pengontrol respon emosi, dan menghambat asetylcholine, serotonis dan neurotransmiter yang lain yang memproduksi sekresi kortisol. Sehingga akan terjadi proses homeostasis (keseimbangan). Semua protektor yang ada di dalam tubuh manusia bekerja dengan ketaatan beribadah, lebih mendekatkan diri kepada Allah SWT dan pandai bersyukur sehingga tercipta suasana keseimbangan dari neurotransmitter yang ada di dalam otak (Erita, 2014; Kholilah, 2017).

Shalat adalah ibadah yang di dalamnya terjadi hubungan rohani antara makhluk dan khaliqnya. Shalat juga dipandang sebagai munajat berdo'a dalam hati yang kushuk kepada Allah. Orang yang sedang mengerjakan shalat dengan kushuk tidak meraaskan sendiri, seolah-olah ia berhadapan dan melakukan dialog dengan tuhan. Suasana spiritual seperti ini dapat menolong manusia untuk mengungkapkan segala perasaan dan berbagaipermasalahan yang dihadapi. Zikir kepada Allah bisa membangkitkan rasa aman, tentram, dalam jiwa karena aktivitas ini merupakan sebentuk terapi bagi kegelisahan yang biasa dirasakan orang saat menghadapi dirinya lemah dan tidak mampu menghadapi tekanan dan bahaya. Bagi orang-orang yang beriman, dengan berdoa segala kesulitan dapat dihadapi dengan tenang karena dengan berdoa kepada Allah yang maha mendengar dan maha mengabulkan doa, maka harapannya akan bersemi kembali dan kesulitannya bisa diatasi. Sebagai mahkluk ciptaan Tuhan kita diwajibkan untuk berbakti kepadaNya, tapi terkadang kita tidak menjalankan secara maksimal atau khusuk karena lemahnya keimanan, keterbatasan waktu dan situasi yang tidak mendukung. Dengan terapi Psikoreligi jika dilaksanakan secara lebih maksimal atau khusuk akan menjadi tindakan yang efektif menurunkan perilaku kekerasan pada pasien skhizofrenia di Rumah Sakit Jiwa (RSJ terapi psikoreligi berpengaruh menurunkan perilaku kekerasan pada pasien. Penurunan ini meliputi penurunan pada

Teguh Pribadii", Djunizar Djamaludin ${ }^{2}$ Program Studi llmu Keperawatan, Fakultas Kedokteran

Universitas Malahayati Bandar Lampung. ${ }^{*}$ Email: teguh@malahayati.ac.id 
Terapi psikoreligi terhadap penurunan perilaku kekerasan pada pasien Skizofrenia di ruang rawat inap Rumah Sakit Jiwa Daerah Provinsi Lampung

respon fisik. Didalam ajaran agama manapun bahwa sesorang yang akan melakukan Doa, Dzikir dan mengikuti ceramah agama disunahkan untuk mensucikan diri, khusus dalam ajaran islam (berwudhlu). Menurut H.R Buchori Muslim bahwa air wudhlu dapat merangsang syaraf yang ada pada tubuh kita. Dengan demikian aliran darah yang ada pada tubuh kita menjadi lancar, sehingga tubuh kita akan menjadi rilek dan akan menurunkan ketegangan. Dimana kalau kondisi tegang tidak segera dinetralisir akan berdampak kemarahan. Kemarahan merupakan salah satu tanda dari perilaku kekerasan. Hal ini juga didukung oleh pendapat Ilham 2008, bahwa terapi psikoreligi yang meliputi doa-doa, dzikir, ceramah keagamaan, dan lain-lain dapat meningkatkan kekebalan dan daya tahan dalam menghadapi berbagai problem kehidupan yang merupakan stressor psikososial guna peningkatan integrasi kesehatan jiwa. Dari sudut ilmu kedokteran jiwa atau keperawatan jiwa atau kesehatan jiwa, doa dan dzikir (psikoreligius terapi) merupakan terapi psikiatrik setingkat lebih tinggi daripada psikoterapi biasa (Ilham, 2008; Keliat, 2010).

Dengan demikian orang yang mengikuti terapi psikoreligi akan membatasi geraknya karena dia berfokus pada kegiatanya sehingga dapat mengurangi agresif fisik klien (Videbeck, 2008). Respon fisik akan mempengaruhi respon emosi. Respon fisik merupakan respon yang meng ikuti perubahan kognitif pada klien perilaku kekerasan (Kusumawati, \& Hartono, 2010). Berdasarkan model adaptasi Stuart menjelaskan bahwa penilaian seseorang terhadap stressor memberikan makna dan dampak dari suartu situasi yang menekan dan ditunjukkan dengan respon kognitif, afektif, respon fisik, respon perilaku dan social (Stuart \& Sundeen, 2007; Sulistyowati, \& Prihantini, 2015; Elliya, \& Pribadi, 2016).

Pendekatan keagamaan dalam praktek kedokteran dan keperawatan dalam dunia kesehatan, bukan untuk tujuan mengubah keimanan seseorang terhadap agama yang sudah diyakininya, melainkan untuk membangkitkan kekuatan spiritual dalam menghadapi penyakit merupakan terapi psikoreligius (Yosep, 2009). Dengan terapi psikoreligi akan melakukan kontrol terhadap emosi yang mempengaruhi proses fikir serta ketegangan otot (Stuart \& Sundeen, 2008). Oleh karenanya peneliti ingin menggunakan serangkaian terapi psikoreligius tersebut dalam penelitian ini. Untuk itu peneliti tertarik melakukan penelitian tentang "Pengaruh Terapi Psikoreligi Terhadap Penurunan Perilaku Kekerasan Pada Pasien Skizofernia Di Ruang Rawat Inap Rumah Sakit Jiwa Daerah Provinsi Lampung Tahun 2018"

\section{METODE PENELITIAN}

Penelitian kuantitatif, dilakukan pada bulan Agustus - Oktober 2019 dengan rancangan penelitian quasi eksperimen. Populasi penelitian adalah semua pasien yang mempunyai riwarat perilaku kekerasan dengan Skreening dengan RUFA 2 (11-21) pasien beragama Islam di ruang rawat inap Rumah Sakit Jiwa Provinsi Lampung sejumlah 30 pasien sebagai sampel. Adapun variabel dependen/terikatnya perilaku kekerasan dan variabel independent/bebasnya terapi psikoreligius. Surat keterangan kelaikan etik didapatkan dengan No. 430/EC/KEPUNMAL//2019. Alat ukur yang digunakan berupa lembar observasi pasien perilaku kekerasan yang meliputi pengkajian tentang tanda dan gejala pasien perilaku kekerasan, data demografi, dan terapi psikoreligi. Pasien yang akan dijadikan objek penelitian dilakukan skrining RUFA 2 (11-21). Setelah melengkapi data demografi lengkap dan responden sudah sesuai dengan kriteria inklusi. Inform consent/persetujuan untuk ikut penelitian didapatkan dari keluarga pasien, karena pasien gangguan jiwa termasuk golongan lemah/vulnerable. Lembar observasi perilaku kekerasan pasien mempnyai 11 observasi kejadian dalam waktu 24 jam tanda dan gejala perilaku kekerasan jika "ada/didapatkan" diberi nilai 1 dan jika "tidak ada (tidak terdapat)" diberi nilai 0 , dan setiap item ada 3 poin observasi sehingga skor terendah 0 dan tertinggi 33. Semua data yang terkumpul kemudian dilakukan pengolahan data. Analisa univariat dilakukan untuk mendapatkan gambaran statistik deskriptif dari masing-masing variabel, baik variabel independen maupun dependen. Analisis bivariat yang digunakan adalah uji $t$-dependent dengan bantuan komputer.

Teguh Pribadi ${ }^{*}$, Djunizar Djamaludin ${ }^{2}$ Program Studi llmu Keperawatan, Fakultas Kedokteran Universitas Malahayati Bandar Lampung.*Email: teguh@malahayati.ac.id 
Terapi psikoreligi terhadap penurunan perilaku kekerasan pada pasien Skizofrenia di ruang rawat inap Rumah Sakit Jiwa Daerah Provinsi Lampung

HASIL

Tabel 1. Karakteristik Responden $\mathrm{N}=30$

\begin{tabular}{lcc}
\hline Variabel & Frekuensi (f) & Persentase (\%) \\
\hline Usia & & \\
20-29 Tahun & 16 & 53.3 \\
30-39 Tahun & 10 & 33.3 \\
40-49 Tahun & 4 & 13.3 \\
Pendidikan & & \\
SD & 4 & 13.3 \\
SMP & 12 & 40.0 \\
SMA & 12 & 40.0 \\
Perguruan & 2 & 6.7 \\
Tinggi & & \\
Pekerjaan & & \\
Tidak bekerja & 24 & 80.0 \\
IRT & 2 & 6.7 \\
Pegawai Swasta & 4 & 13.3 \\
\hline
\end{tabular}

Berdasarkan tabel diatas diketahui bahwa sebagian besar responden dengan berusia antara 20-29 tahun, yaitu sebanyak 16 responden (53.2\%), berpendidikan akhir SMP dan SMA yaitu masing-masing sebanyak 12 responden (40.0\%), sebagian besar responden adalah tidak bekerja sebanyak 24 responden (80.0\%).

Tabel 2. Tabel Analisis Selisih Nilai Perilaku Kekerasan Kelompok Intervensi Dan Kelompok Kontrol Sebelum Dan Setelah Terapi Psikoreligi N=30

\begin{tabular}{|c|c|c|c|c|}
\hline Variabel & $\mathrm{n}$ & Mean \pm SD & $t$ & $p$-value \\
\hline $\begin{array}{l}\text { Perilaku kekerasan } \\
\text { sebelum (Kelompok } \\
\text { Intervensi) }\end{array}$ & 15 & $16,87 \pm 1,46$ & 11,50 & 0,00 * \\
\hline $\begin{array}{l}\text { Perilaku kekerasan } \\
\text { sesudah (Kelompok } \\
\text { Intervensi) }\end{array}$ & 15 & $13,0 \pm 1.00$ & & \\
\hline $\begin{array}{l}\text { Perilaku kekerasan } \\
\text { sebelum (Kelompok } \\
\text { Tanpa Intervensi) }\end{array}$ & 15 & $18,20 \pm 2,21$ & 5,12 & $0,00^{*}$ \\
\hline $\begin{array}{l}\text { Perilaku kekerasan } \\
\text { sesudah (Kelompok } \\
\text { Tanpa Intervensi) }\end{array}$ & 15 & $16,20 \pm 2.11$ & & \\
\hline
\end{tabular}

Berdasarkan tabel diatas diketahui bahwa rata-rata Skor perilaku kekerasan Sebelum Terapi psikoreligi adalah 16,87 dengan standar deviasi 1,46 sedangkan rata-rata Skor perilaku kekerasan sesudah Terapi psikoreligi adalah 13.0 dengan standar deviasi 1,0. Dari hasil uji statistik di atas didapatkan thitung $=11,502$. Karena $t_{\text {hitung }}>t_{\text {tabel }}$ yaitu $11.502>0,021$ dan $p$-value $=0,000$, maka dapat disimpulkan ada pengaruh terapi psikoreligi terhadap penurunan perilaku kekerasan sangat signifikan dibandingkan kelompok kontrol (tanpa dilakukan terapi psikoreligi).

Teguh Pribadi ${ }^{*}$, Djunizar Djamaludin ${ }^{2}$ Program Studi llmu Keperawatan, Fakultas Kedokteran Universitas Malahayati Bandar Lampung.*Email: teguh@malahayati.ac.id 
Terapi psikoreligi terhadap penurunan perilaku kekerasan pada pasien Skizofrenia di ruang rawat inap Rumah Sakit Jiwa Daerah Provinsi Lampung

\section{PEMBAHASAN}

Skizoprenia merupakan suatu sindrome klinis atau proses penyakit yang mempengaruhi kognisi, persepsi, emosi, perilaku, dan fungsi sosial, tetapi skizoprenia mempengaruhi setiap individu dengan cara yang berbeda. Derajat gangguan pada fase akut atau fase psikotik dan fase kronis atau fase jangka panjang sangat bervariasi diantara individu (Muhtih, 2015).

Masalah keperawatan yang sering muncul pada penderita skizoprenia adalah perilaku kekerasan. Menurut Stuart dan Sundeen (2007) ada 3 strategi dalam manajemen perilaku kekerasan, yaitu strategi pencegahan, antisipasi, dan pengekangan. Terapi Psikoreligi merupakan bagian dari latihan assertive, sehingga terapi Psikoreligi masuk dalam strategi pencegahan (Marlindawani, 2009; Syam, 2010).

Sebagai mahkluk ciptaan Tuhan kita diwajibkan untuk berbakti kepadaNya, tapi terkadang kita tidak menjalankan secara maksimal atau khusuk karena lemahnya keimanan, keterbatasan waktu dan situasi yang tidak mendukung. Dengan terapi Psikoreligi jika dilaksanakan secara lebih maksimal atau khusuk akan menjadi tindakan yang efektif menurunkan perilaku kekerasan pada pasien skhizofrenia di Rumah Sakit Jiwa terapi psikoreligi berpengaruh menurunkan perilaku kekerasan pada pasien. Penurunan ini meliputi penurunan pada respon fisik. Didalam ajaran agama manapun bahwa sesorang yang akan melakukan Doa, Dzikir dan mengikuti ceramah agama disunahkan untuk mensucikan diri, khusus dalam ajaran islam (berwudhu).

Menurut H.R Buchori Muslim bahwa air wudhlu dapat merangsang syaraf yang ada pada tubuh kita. Dengan demikian aliran darah yang ada pada tubuh kita menjadi lancar, sehingga tubuh kita akan menjadi rilek dan akan menurunkan ketegangan. Dimana kalau kondisi tegang tidak segera dinetralisir akan berdampak kemarahan. Kemarahan merupakan salah satu tanda dari perilaku kekerasan. Hal ini juga didukung oleh pendapat Ilham 2008, bahwa terapi psikoreligi yang meliputi doa-doa, dzikir, ceramah keagamaan, dan lain-lain dapat meningkatkan kekebalan dan daya tahan dalam menghadapi berbagai problem kehidupan yang merupakan stressor psikososial guna peningkatan integrasi kesehatan jiwa. Dari sudut ilmu kedokteran jiwa atau keperawatan jiwa atau kesehatan jiwa, doa dan dzikir (psikoreligius terapi) merupakan terapi psikiatrik setingkat lebih tinggi dari pada psikoterapi biasa (Ilham, 2008; Ariyan, 2014).

Dengan demikian orang yang mengikuti terapi psikoreligi akan membatasi geraknya karena dia berfokus pada kegiatanya sehingga dapat mengurangi agresif fisik klien (Videbeck, 2008; Sulistyowati, \& Prihantini, 2015). Respon fisik akan mempengaruhi respon emosi. Respon fisik merupakan respon yang meng ikuti perubahan kognitif pada klien perilaku kekerasan (Boyd \& Nihart, 1998; Sulistyowati, \& Prihantini, 2015). Berdasarkan model adaptasi Stuart menjelaskan bahwa penilaian seseorang terhadap stressor memberikan makna dan dampak dari suartu situasi yang menekan dan ditunjukkan dengan respon kognitif, afektif, respon fisik, respon perilaku dan social (Rahayu, 2008).

Pendekatan keagamaan dalam praktek kedokteran dan keperawatan dalam dunia kesehatan, bukan untuk tujuan mengubah keimanan seseorang terhadap agama yang sudah diyakininya, melainkan untuk membangkitkan kekuatan spiritual dalam menghadapi penyakit merupakan terapi psikoreligius (Yosep, 2009). Dengan terapi psikoreligi akan melakukan kontrol terhadap emosi yang mempengaruhi proses fikir serta ketegangan otot (Stuart \& Sundeen, 2005; Putri, 2010).

Hasil penelitian ini sejalan dengan penelitian yang dilakukan oleh Sulistyowati, \& Prihantini (2014) tentang pengaruh terapi psikoreligi terhadap penurunan perilaku kekerasan pada pasien skizofrenia di Rumah Sakit Jiwa Daerah Surakarta Hasil penelitian menunjukkan bahwa Terapi Psikoreligius berpengaruh terhadap penurunan perilaku kekerasan.

\section{KETERBATASAN PENELITIAN}

Adanya kemungkinan faktor lainya dalam penelitian ini yang dapat berpengaruh terhadap menurunkan perilaku kekerasan pada pasien seperti; semua kelompok selama terapi psikoreligi masih mendapatkan terapi anti psikotik yang tentunya secara medis dapat memberikan ketenangan dan menghilangkan gejala psikotik seperti; halusinasi pendengaran dan penglihatan.

Disamping itu ada beberapa pasien yang mendapatkan kunjungan keluarga sehingga mereka mendapatkan perhatian dan dukungan sosial keluarga.

Teguh Pribadi ${ }^{*}$, Djunizar Djamaludin ${ }^{2}$ Program Studi llmu Keperawatan, Fakultas Kedokteran

Universitas Malahayati Bandar Lampung.*Email: teguh@malahayati.ac.id 
Terapi psikoreligi terhadap penurunan perilaku kekerasan pada pasien Skizofrenia di ruang rawat inap Rumah Sakit Jiwa Daerah Provinsi Lampung

\section{SIMPULAN}

Rata-rata Skor perilaku kekerasan Sebelum Terapi psikoreligi adalah 16,87 (standar deviasi 1.46), Rata-rata Skor perilaku kekerasan sesudah Terapi psikoreligi adalah 13.0 (standar deviasi 1.0). Ada pengaruh terapi psikoreligi terhadap penurunan perilaku kekerasan pada pasien skizopfrenia di Ruang Rawat Inap Rumah Sakit Jiwa Daerah Provinsi Lampung Tahun 2019 (p value 0,000$)$.

\section{SARAN}

Bagi instansi dan manajemen rumah sakit jiwa yang telah melakukan kegiatan kerohanian pada pasien skizoprenia supaya lebih ditingkatkan dengan tambahan terapi psikorelegi. Perlunya pelatihan para perawat dalam memberikan asuhan keperawatan khususnya terapi psikoreligi dan merupakan keterampilan baru.

Bagi penelitian selanjut nya diharapkan dapat melakukan penelitian lebih dalam lagi seperti di bidang religi melihat sholat yang dilakukan, membaca Al-quran, dan etiologi-etiologi lain yang menyebabkan perilaku kekerasan sehingga dapat dilakukan penanganan yang baik.

\section{UCAPAN TERIMA KASIH}

Kepada Kementerian Riset, Teknologi, dan Pendidikan Tinggi Republik Indonesia karena telah memberikan dana penelitian melalui skema Penelitian Dosen Pemula.

\section{DAFTAR PUSTAKA}

Damayanti, M. (2008). Komunikasi Terapeutik Dalam Keperawatan. Bandung: Refika Aditama

Elliya, R., \& Pribadi, T. (2016). Perbedaan teknik relaksasi otot progresif dan imajinasi terbimbing dalam penurunan tingkat stres pada pasien pre-operasi di ruang mawar RSUD DR. H. Abdul Moeloek Tahun 2015. Holistik Jurnal Kesehatan, 10(3), 159-168
Fanada, M. (2012). Perawat dalam penerapan therapi psikoreligius untuk menurunkan tingkat stress pada pasien halusinasi pendengaran di rawat inap bangau rumah sakit ernaldi bahar Palembang. Badan Diklat Provinsi Sumatera Selatan. Di akses dari http://www. banyuasink ab. go. id/tampung/dokumen/dokumen-15-34. $p d f$.

Gusdiansah, E. (2016). Pengaruh Psikoedukasi Keluarga Terhadap Klien Dan Kemampuan Klien Perilaku Kekerasan Dan Kemampuan Keluarga Dalam Merawat Dirumah

Hawari, D. (2001). Pendekatan holistik pada gangguan jiwa skizofrenia. Jakarta: FKUI.

Keliat, B.A. (2010). Model Praktik Keperawatan Profesional Jiwa. Jakarta: EGC.

Kementrian Kesehatan Republik Indonesia. (2013). Riset Kesehatan Dasar Republik Indonesia Tahun 2013. Jakarta

Kusuma, Y. L. H. (2015). Pengaruh Bimbingan Metode Diskusi Terhadap Perubahan Harga Diri Narapidana Di Lapas Kelas II B Kota Mojokerto. Hospital Majapahit (Jurnal IImiah Kesehatan Politeknik Kesehatan Majapahit Mojokerto), 7(2).

Kusumawati, F., \& Hartono, Y. (2010). Buku ajar keperawatan jiwa. Jakarta: Salemba Medika, 59-75.

Maramis. (2009). Catatan IImu Kedokteran Jiwa Edisi 2. Surabaya: Pusat Penerbitan dan Percetakan UNAIR.

Muhith, A. (2015). Pendidikan keperawatan jiwa: Teori dan aplikasi. Penerbit Andi.Notoatmodjo, S. (2010).Metodologi Penelitian Kesehatan Edisi Revisi. Jakarta :Rineka Cipta.

Putri, D. E. (2010). Pengaruh Rational Emotive Behaviour Therapy Terhadap Perilaku Kekerasan,Tesis. Jakarta. FIK UI.

Teguh Pribadi ${ }^{*}$, Djunizar Djamaludin ${ }^{2}$ Program Studi llmu Keperawatan, Fakultas Kedokteran Universitas Malahayati Bandar Lampung.*Email: teguh@malahayati.ac.id 
Terapi psikoreligi terhadap penurunan perilaku kekerasan pada pasien Skizofrenia di ruang rawat inap Rumah Sakit Jiwa Daerah Provinsi Lampung

Rumah Sakit Jiwa Provinsi Lampung. (2017). Medical rekor perilaku kekerasan pasien dengan skizoprenia.

Siswanto, S., Susila, D., \& Suyanto, D. (2013). Metodologi Penelitian Kesehatan dan Kedokteran. Yogyakarta: Bursa IImu.

Stuart, G. W., \& Sundeen, S. J. (2007). Buku saku keperawatan jiwa. Jakarta: EGC .

Sugiyono.(2012). Metode Penelitian Kuantitatif, Kualitatif dan Kombinasi. Bandung: Alfabeta.

Sulastri, S. (2010).Pengaruh Penerapan Asuhan Keperawatan Dalam Mengontrol Gejala Halusinasi Pasien. Skripsi Tidak diterbitkan.
Sulistyowati, D. A., \& Prihantini, E. (2015). Pengaruh Terapi Psikoreligi Terhadap Penurunan Perilaku Kekerasan pada Pasien Skizofrenia di Rumah Sakit Jiwa Daerah Surakarta. Interest: Jurnal IImu Kesehatan, 4(1).

Suryani, (2013). Setiap Tahun Penderita Gangguan Jiwa di Indonesia Terus Meningkat. Bandung: Universitas Padjadjaran.

Videbeck, S. L. (2008). Buku ajar keperawatan jiwa. Jakarta: Egc, 45, 2010-2011.

Yosep, I. (2009). Keperawatan Jiwa. Bandung :Refika Aditama.

Teguh Pribadi ${ }^{*}$, Djunizar Djamaludin ${ }^{2}$ Program Studi llmu Keperawatan, Fakultas Kedokteran Universitas Malahayati Bandar Lampung.*Email: teguh@malahayati.ac.id 